\title{
Temperature-sensitive $v$-sea transformed erythroblasts: a model system to study gene expression during erythroid differentiation
}

\author{
Jennifer Knight, ${ }^{1}$ Martin Zenke, ${ }^{2}$ Christine Disela, ${ }^{2}$ Elisabeth Kowenz,, ${ }^{1}$ Peter Vogt, ${ }^{3}$ \\ J. Douglas Engel, ${ }^{4}$ Michael J. Hayman, ${ }^{1}$ and Hartmut Beug ${ }^{2}$ \\ ${ }^{1}$ State University of New York, Department of Microbiology, Stony Brook, New York 11790 USA; ${ }^{2}$ European Molecular \\ Biology Laboratory (EMBL), Differentiation Programme, 6900 Heidelberg, Federal Republic of Germany; ${ }^{3}$ University of \\ Southern California, Los Angeles, California 90033 USA; ${ }^{4}$ Northwestern University, Department of Biochemistry, Molecular, \\ and Cell Biology, Evanston, Illinois 60201 USA
}

\begin{abstract}
The isolation and characterization of a temperature-sensitive mutant (ts1 S13) of the avian erythroblastosis virus, $S 13$, is described. The temperature-sensitive lesion in ts1 S13 was identified as affecting the tyrosine kinase activity but not the plasma membrane localization of the ts1 S13 v-sea gene product. Erythroblasts transformed by $t s 1 \mathrm{~S} 13$ can be induced to synchronously differentiate into erythrocytes in an erythropoietin (EPO)-dependent fashion. Analysis of erythrocyte-specific gene expression in ts1 S13 erythroblasts reveals that the transformed, self-renewing erythroblasts obtained at permissive temperature already express all erythrocyte genes tested for, although at a low level. Upon differentiation induction, expression of erythrocyte-specific genes is not coordinately regulated but rather involves complex regulatory mechanisms that appear to be specific for the individual genes.
\end{abstract}

[Key Words: Erythroid differentiation; sea oncogene]

Received August 20, 1987; revised version accepted December 10, 1987.

Erythroid differentiation is a particularly prominent and well-studied example of how the pattern of gene expression changes during terminal differentiation. During maturation of erythroid progenitors into erythrocytes, relatively few genes such as those encoding globins, cytoskeletal proteins, and erythrocyte-specific enzymes are induced to be expressed at very high level, whereas expression of a multitude of other genes (including those encoding 'housekeeping proteins' $\mid$ is shut down or diminished (for review, see Harrison 1984). Unlike other in vitro differentiation systems (e.g., myoblasts), in which the progenitors become postmitotic before reprogramming of the gene-expression pattern occurs, maturing avian erythroid progenitors (colony forming unit erythroid, CFU-E) undergo four to five cell divisions while actively accumulating red cell proteins (Holtzer et al. 1972). Therefore, analysis of red cell differentiation is a particularly well-suited system in which to study the regulation of tissue-specific gene expression (Choi and Engel 1986; Emerson et al. 1985). In addition, it promises to yield new insights into the interdependence of proliferation and differentiation (Falcone et al. 1984; Blau et al. 1985).

Erythroid progenitors cannot be purified in sufficient quantities for biochemical or molecular studies (van
Zant and Goldwasser 1984). Thus, gene expression during erythroid differentiation has mainly been studied in immature red cells from chick embryos (Blikstad et al. 1983), reticulocytes from anemic animals (BonanovTzedaki et al. 1981), or erythroleukemic cell lines of mouse (Friend erythroleukemia cells) or human (K562, $\mathrm{KD}$ ) origin. However, the first two approaches preclude analysis of very early, dividing progenitor cells such as CFU-Es, whereas the drug-induced differentiation of erythroleukemic cell lines is usually incomplete and independent of erythropoietin (Houseman et al. 1978; Marks and Rifkind 1978).

Some progress towards overcoming these problems was made by using clones of avian erythroid progenitors transformed by temperature-sensitive mutants of the avian erythroblastosis virus (AEV) (Graf et al. 1978). These AEV mutants encode a thermosensitive v-erbB protein exhibiting a single amino acid exchange in the erbB-kinase domain (Choi et al. 1986; Scotting et al. 1987), as well as an apparently unchanged v-erbA protein. When erythroblasts transformed by these temperature-sensitive (ts) AEV mutants are shifted to the nonpermissive temperature, the proliferating, erythropoietin (EPO)-independent erythroblasts are both induced to differentiate into erythrocytes within $4-5$ days and 
become dependent on EPO for survival and differentiation (Beug et al. 1982; Beug and Hayman 1984). However, we have found recently that the v-erbA oncogene, a mutated version of the thyroid hormone receptor (Sap et al. 1986), drastically affects the transcription of certain erythrocyte-specific genes, leading to a differentiation arrest of temperature-induced temperature-sensitive $\mathrm{AEV}$ cells under certain conditions ( $\mathrm{M}$. Zenke et al., in prep.). In addition, the temperature-sensitive lesion in the v-erbB protein affects its cell-surface expression but does not abolish its tyrosine kinase activity, leading to a detectable 'leakiness' of the temperature-sensitive-erbB mutation (H. Beug et al., in prep.).

These problems were successfully overcome by use of a temperature-sensitive mutant of the avian erythroblastosis virus S13 (Benedict et al. 1985; Beug et al. 1985b|. Here we describe the characterization of this mutant (ts $1 \mathrm{~S} 13$ ) and demonstrate its utilization in studying erythrocyte-specific gene expression during terminal differentiation. The $\mathrm{v}$-sea oncogene product (gp 155/70 env-sea), represents a tyrosine kinase domain that is fused to the carboxyl terminus of the viral envelope glycoprotein (Hayman et al. 1985). We will demonstrate that the thermosensitive lesion in the ts 1 S13 gp 155/70 env-sea proteins causes an almost complete inactivation of their associated kinase activity, thus leading to a nonleaky temperature-sensitive phenotype of the mutant in both fibroblasts and erythroblasts. Analysis of erythrocyte protein and RNA expression during EPO-dependent, synchronous differentiation of these ts $1 \mathrm{~S} 13$ cells at $42^{\circ} \mathrm{C}$ reveals that self-renewal of the transformed cells at $37^{\circ} \mathrm{C}$ is compatible with low-level expression of most, if not all, erythrocyte-specific genes. Terminal differentiation, on the other hand, is characterized by a massive increase in transcription of some, but not all of the erythrocyte-specific genes studied.

\section{Results}

ts1 S13 exhibits a thermosensitive phenotype in fibroblasts

The $t s 1$ S13 mutant was detected as a spontaneous mutant upon biological cloning of several S13 isolates in nonproducer erythroblasts (Beug et al. 1985b). Upon repeated recloning, the temperature-sensitive phenotype of the $t s 1 \mathrm{~S} 13$ mutant remained associated with this particular virus isolate, whereas erythroblasts transformed with several other S13 substrains exhibited a wild-type phenotype (Graf et al. 1978; P. Vogt and H. Beug, unpubl.). To study whether the $t s 1$ S13 virus would exhibit a temperature-sensitive phenotype in chick embryo fibroblasts (CEFs), ts1 S13- and wt-S13-virus-transformed CEFs were assayed for the expression of several fibroblast transformation parameters (Royer-Pokora et al. 1978; see Materials and methods). Table 1 shows that ts $1 \mathrm{~S} 13$ fibroblasts maintained at $42^{\circ} \mathrm{C}$ for $24 \mathrm{hr}$ were essentially indistinguishable from normal helper virusinfected fibroblasts, except for a slightly enhanced capacity to form minute colonies in soft agar. At the per- missive temperature $\left(37^{\circ} \mathrm{C}\right)$, ts $1 \mathrm{~S} 13$ fibroblasts exhibited a strongly transformed phenotype, characterized by fusiform morphology, absence of actin filament bundles, greatly reduced fibronectin network, strongly enhanced hexose transport rate, and efficient colony formation in soft agar. Except for some difference in hexose transport rate, the respective wt $\mathrm{S} 13$-transformed fibroblasts exhibited a strongly transformed phenotype at both $37^{\circ} \mathrm{C}$ and $42^{\circ} \mathrm{C}$ (Table 1). Thus, in contrast to the partial temperature-sensitive phenotypes observed with the available temperature-sensitive AEV mutants (Beug and Graf 1980; Palmieri et al. 1982), the ts $1 \mathrm{~S} 13$ virus induces a complete temperature-sensitive phenotype in CEFs.

Synchronous, hormone-dependent differentiation of ts 1 $S 13$ erythroblasts at the nonpermissive temperature

To isolate well-diferentiating $t s 1 \mathrm{~S} 13$ erythroblast clones exhibiting an in vitro life span long enough to allow production of erythroid cells at different stages of maturation in sufficient numbers for biochemical experiments, more than 100 ts 1 S13-transformed clones (Beug et al. 1985b) were screened for completeness of terminal differentiation, yield of differentiated cells, and in vitro life span, as described previously (Beug and Hayman 1984; Kowenz et al. 1987). In contrast to temperature-sensitive AEV clones, all temperature-sensitive S13 erythroblast clones tested exhibited essentially complete differentiation after $3-4$ days at $42^{\circ} \mathrm{C}$, with the viable cell population consisting of more than $95 \%$ mature cells (erythrocytes plus late reticulocytes). However, considerable variation was seen between different clones with respect to in vitro life span (15 to $>40$ population doublings in culture, clones with high life span occurring more infrequently), proportion of viable differentiated cells $(20 \%$ to $\geqslant 95 \%$ after 3 days), and yield of differentiated cells $10.5 \times 10^{6}$ to $5 \times 10^{6}$ cells obtained from $1 \times 10^{6}$ cells induced to differentiate).

In Table 2 and Figure 1, the properties of two ts $1 \mathrm{~S} 13$ clones selected for a particularly long life span and high yield of differentiated cells are shown. Both clones exhibited an in vitro life span of more than 40 generations in culture. Mass populations shifted to the nonpermissive temperature in the presence of EPO contained more than $90 \%$ viable cells after 3 days at $42^{\circ} \mathrm{C}$ (Table 2) and yielded $3 \times 10^{6}$ to $5 \times 10^{6}$ mature cells per $10^{6}$ induced cells (data not shown). Thus, these clones could be used to produce homogeneous populations of $10^{7}$ to $10^{8}$ erythroid cells at different stages of maturation when shifted to $42^{\circ} \mathrm{C}$ for various lengths of time, as demonstrated by morphology, hemoglobin content, and size distribution (Fig. 1).

tsl S13-transformed erythroblasts were also clearly dependent on chicken EPO for survival, proliferation, and differentiation. Studies using more than 2000-fold purified chicken EPO, representing an acidic glycoprotein of approximately 30,000 daltons (Kowenz et al. 1987), clearly show that chicken EPO stimulates both proliferation and hemoglobin accumulation of temperature-induced ts $1 \mathrm{~S} 13$ cells (Fig. 2; Table 2). In contrast to 
Table 1. Transformation parameters of ts1 S13-and wt S13-transformed fibroblasts

\begin{tabular}{|c|c|c|c|c|c|c|}
\hline Virus & $\begin{array}{l}\text { Temperature } \\
\left({ }^{\circ} \mathrm{C} \mid\right.\end{array}$ & Morphology & $\begin{array}{l}\text { Actin } \\
\text { cables } \\
\text { (\% positive) }\end{array}$ & Fibronectin & $\begin{array}{l}\text { Hexose } \\
\text { uptake } \\
\text { (-fold } \\
\text { stimulation })^{\mathrm{a}}\end{array}$ & $\begin{array}{l}\text { Agar } \\
\text { colonies } \\
(\mathrm{cfu} / \mathrm{ml} \mid\end{array}$ \\
\hline \multirow{2}{*}{ ts1 S13 } & 37 & transformed & 15 & - & 5.7 & $5.1 \times 10^{5}$ \\
\hline & 42 & normal & 80 & +++ & 1.2 & $3 \times 10^{3}$ \\
\hline \multirow[t]{2}{*}{ wt S13 } & 37 & transformed & 17 & - & 5.3 & $3.4 \times 10^{4}$ \\
\hline & 42 & transformed & 17 & - & 3.1 & $1.5 \times 10^{4}$ \\
\hline RAV-1 & 37 & normal & 87 & +++ & 1 & $<10^{2}$ \\
\hline
\end{tabular}

For definition of normal and transformed morphology, expression of actin filament bundles, and fibronectin network, see Royer-Pokara et al. (1978) and Palmieri et al. (1982). Hexose uptake data are the mean of three independent determinations. Agar colony formation was determined from counting $>400$ colonies from at least four separate dishes, using 10 -fold serial dilutions of virus.

a Relative to RAV-1-infected fibroblasts.

temperature-sensitive AEV cells (Beug et al. 1982), tsl $\mathrm{S} 13$ cells that survived cultivation at $42^{\circ} \mathrm{C}$ in the absence of EPO still completely differentiated into erythrocytes (Table 2 and data not shown). This indicates that chicken EPO, like other hematopoietic growth factors, is required for survival and proliferation of differentiating precursors but does not appear to control the erythroid differentiation program per se.

The thermosensitive lesion in the gp $155 / g p 70^{\text {env-sea }}$. transforming protein of ts1 S13 affects kinase activity but not intracellular localization

Biosynthesis of the env-sea fusion protein of $\mathrm{S} 13$ virus starts with a gp $155^{\text {env-sea }}$ glycoprotein localized in intracellular membranes (Hayman et al. 1985). Similar to processing of the retroviral env precursor gp 92 into gp $85^{e n v}$ and $g p 37^{\text {env }}$, the gp $155^{\text {env-sea }}$ precursor is cleaved into the transmembrane protein $\mathrm{gp} 70^{\text {env-sea }}$ and mature $\mathrm{gp} 85^{\text {env }}$, leading to insertion of gp $70^{\text {env-sea }}$ into the plasma membrane (Hayman et al. 1985 and unpubl.). To study whether the temperature-sensitive lesion in tsl S13 would affect processing and plasma membrane localization of the $t s-g p 155 / g p 70^{\text {env-sea }}$ protein or, alternatively, would render its associated tyrosine kinase activity

Table 2. Properties of ts1 S13- and wt S13-transformed erythroblast clones

\begin{tabular}{|c|c|c|c|c|c|c|}
\hline \multirow[b]{2}{*}{ Virus } & \multirow{2}{*}{$\begin{array}{l}\text { Clone } \\
\text { no. }\end{array}$} & \multirow{2}{*}{$\begin{array}{l}\text { Temper- } \\
\text { ature } \\
\left({ }^{\circ} \mathrm{C}\right)\end{array}$} & \multicolumn{2}{|c|}{$\begin{array}{l}\text { Percent } \\
\text { LR + E }\end{array}$} & \multicolumn{2}{|c|}{$\begin{array}{c}\text { Percent } \\
\text { viable cells }\end{array}$} \\
\hline & & & $+\mathrm{EPO}$ & $-\mathrm{EPO}$ & $+\mathrm{EPO}$ & $-\mathrm{EPO}$ \\
\hline \multirow[t]{4}{*}{$t s 1 \mathrm{~S} 13$} & $\mathrm{~A} 4$ & 37 & 14 & 15 & 96 & 86 \\
\hline & & 42 & $>98$ & $>98$ & 88 & 44 \\
\hline & $\mathrm{H} 2$ & 37 & 3 & 5 & 80 & 76 \\
\hline & & 42 & $>98$ & $>98$ & 93 & 25 \\
\hline \multirow[t]{4}{*}{ wt S13 } & A1 & 37 & 7 & 8 & 90 & 92 \\
\hline & & 42 & 10 & 12 & 85 & 81 \\
\hline & B3 & 37 & 1 & 1 & 94 & 96 \\
\hline & & 42 & 2 & 3 & 90 & 84 \\
\hline
\end{tabular}

Percentages of late reticulocytes (LR) and erythrocytes (E) were determined in stained cytospin preparations as described earlier (Beug et al. 1982). The percentage of viable cells was determined as in Schmidt et al. (1986c). thermosensitive, pulse-chase analysis of ${ }^{35} \mathrm{~S} \mid \mathrm{methio}$ nine-labeled $t s 1 \mathrm{~S} 13$ and $w t \mathrm{~S} 13$ fibroblasts maintained at $37^{\circ} \mathrm{C}$ or shifted to $42^{\circ} \mathrm{C}$ was performed. Aliquots of the same cell preparations were also tested for in vitro kinase activity, using the immune complex autophosphorylation assay (Hayman et al. 1985, 1986). The results obtained show that gp $155^{\text {env-sea }}$ was processed very inefficiently into $\mathrm{gp} 70^{\text {env-sea }}$ at permissive as well as nonpermissive temperature in both ts $1 \mathrm{~S} 13$ fibroblasts (Fig. 3A) and wt S13 fibroblasts (data not shown). However, autophosphorylation of both $\operatorname{gp} 155^{\text {env-sea }}$ and gp $70^{\text {env-sea }}$ was clearly thermolabile in $t s 1 \mathrm{~S} 13$ fibroblasts (Fig. 3A). As revealed by scanning of different exposures of the gel shown in Figure 3A, the kinase levels of $\mathrm{gp} 155^{\text {env-sea }}$ and $\mathrm{gp} 70^{\text {env-sea }}$ were reduced at least 5 -fold and 20 -fold respectively. In contrast, only a 2.5 -fold decrease in autophosphorylation of gp $70^{\text {env-sea }}$ was seen in wt $\mathrm{S} 13$ cells maintained at $42^{\circ} \mathrm{C}$, whereas the kinase activity of the gp $155^{\text {env-sea }}$ protein remained unchanged. The observed decrease in autophosphorylation of $w t S 13$ gp $70^{\text {env-sea }}$ was a reproducible effect, although other experiments resulted only in a 1.5 - to 2 -fold reduction in activity. This is in accord with the weak temperature sensitivity of hexose uptake in wt $\mathrm{S} 13$ fibroblasts and suggests that gp155 env-sea might be involved in fibroblast transformation.

The temperature-sensitivity of kinase activity of the ts 1 S13-transforming proteins was even more striking in erythroblasts. In these cells, gp155 env-sea is processed rather rapidly into gp $70^{\text {env-sea }}$, and processing seems to be somewhat inhibited at $42^{\circ} \mathrm{C}$ in $t s 1 \mathrm{~S} 13$ erythroblasts but not in wt S13 erythroblasts (Fig. 3B; J. Knight and M. Hayman, unpubl.). Figure $3 \mathrm{~B}$ demonstrates that the in vitro kinase activity of both gp $155^{\text {env-sea }}$ and gp $70^{\text {env-sea }}$ was drastically reduced $1>10$-fold and $>30$-fold, respectively) if the cells were kept at $42^{\circ} \mathrm{C}$ for 24 hours. Likewise, $g p 70^{\text {env-sea }}$ could be efficiently labeled in vivo with inorganic phosphate at $37^{\circ} \mathrm{C}$, and this labeling was again reduced more than 10 -fold after 24 hours at $42^{\circ} \mathrm{C}$. Control experiments performed with wt S13-transformed erythroblasts revealed that autophosphorylation of gp $155^{\text {env-sea }}$ and gp $70^{\text {env-sea }}$ was only slightly reduced $\mid<3$ fold) by shift to the nonpermissive temperature (data not shown). 
Figure 1. Synchronous, temperature-induced differentiation of ts 1 S13-transformed erythroblasts. ts $1 \mathrm{~S} 13$ erythroblasts (clone $\mathrm{A} 4$ ) were grown at $37^{\circ} \mathrm{C}$ or shifted to $42^{\circ} \mathrm{C}$ for the times indicated, purified (see Materials and methods), and analyzed for morphology and hemoglobin content by histochemical staining (left panels) or for their size distribution (right panels) using a Coulter counter (see Material and methods). Photographs (left panels) were taken under blue light (Beug et al. 1982) to reveal histochemical staining for hemoglobin. (Inset, bottom left panel) Terminally differentiated $t s 1 \mathrm{~S} 13$ cells photographed under green light to reveal histological details.

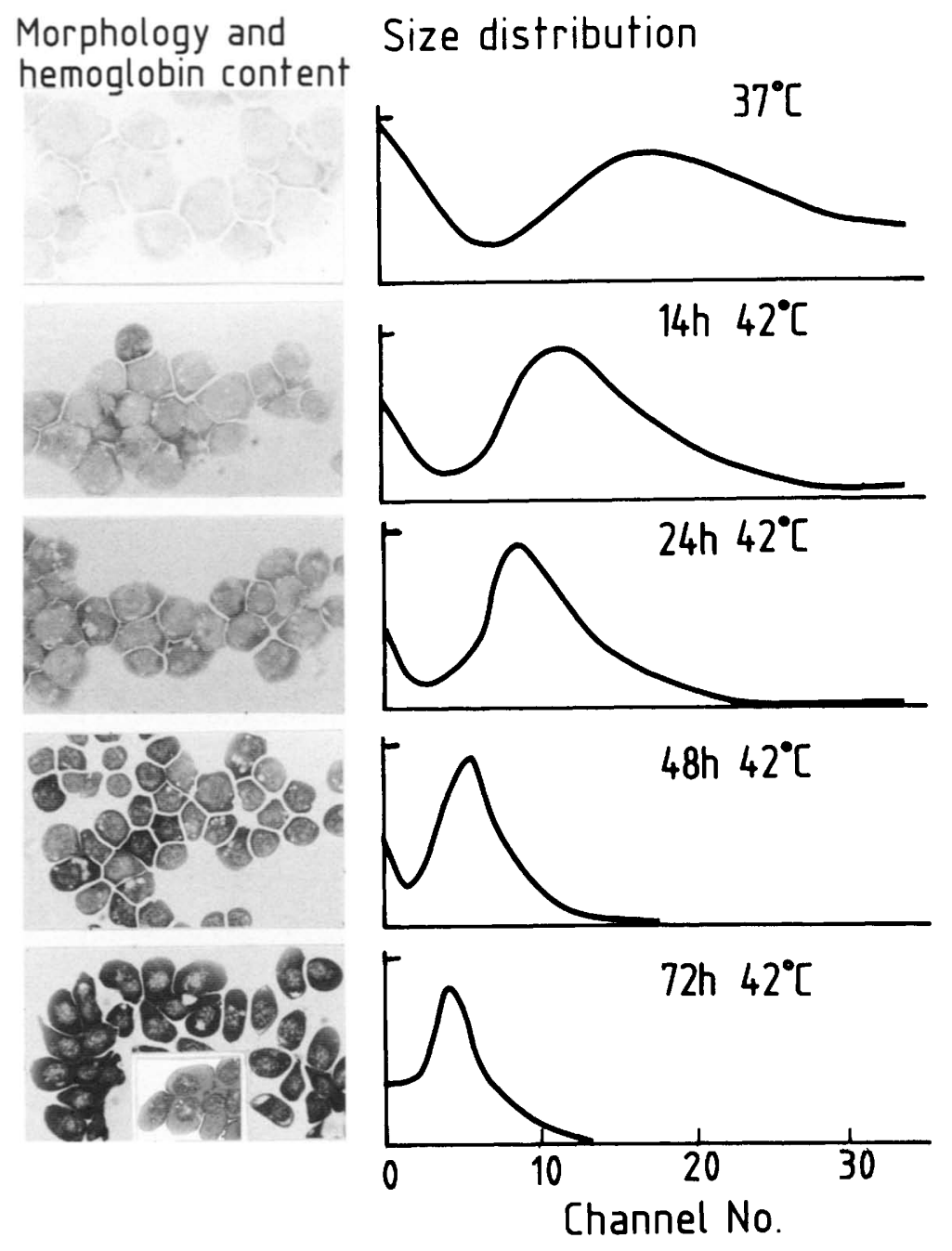

Taken together, our results clearly demonstrate that the putative temperature-sensitive lesion in the gp155/ gp70env-sea proteins of $t s 1 \mathrm{~S} 13$ affects their autophosphorylation on tyrosine both in vitro and in vivo but does not grossly alter the processing and maturation of the env-sea fusion proteins. The latter conclusion was confirmed by studying cell-surface expression of the gp155/70 env-sea protein in tsl S13-transformed erythroblasts and fibroblasts, using a tumor-bearing rat serum to gp $155 / 70^{e n v-s e a}$ that recognized an external env-determinant specific for the S13-transforming protein (Hayman et al. 1985). Figure 4 demonstrates that gp155/ $70^{\text {env-sea }}$ behaves differently than $\mathrm{gp} 70$ erbB (Beug and Hayman 1984) in that these proteins continued to be ex-

Figure 2. Proliferation and hemoglobin production of differentiating $t s 1 \mathrm{~S} 13$ cells are erythropoietin- dependent. $t s 1 \mathrm{~S} 13$ cells were grown at $37^{\circ} \mathrm{C}$ (upper panel) or shifted to $42^{\circ} \mathrm{C}$ (lower panel/ in the presence of different concentrations of $>2000$-fold purified chicken EPO and assayed in the DNA synthesis assay (O) or the photometric assay (A) for EPO activity as described in Kowenz et al. (1987). As controls $(O, \triangle)$, inactive fractions from the final reverse-phase HPLC run (Kowenz et al. 1987) were included in the test.

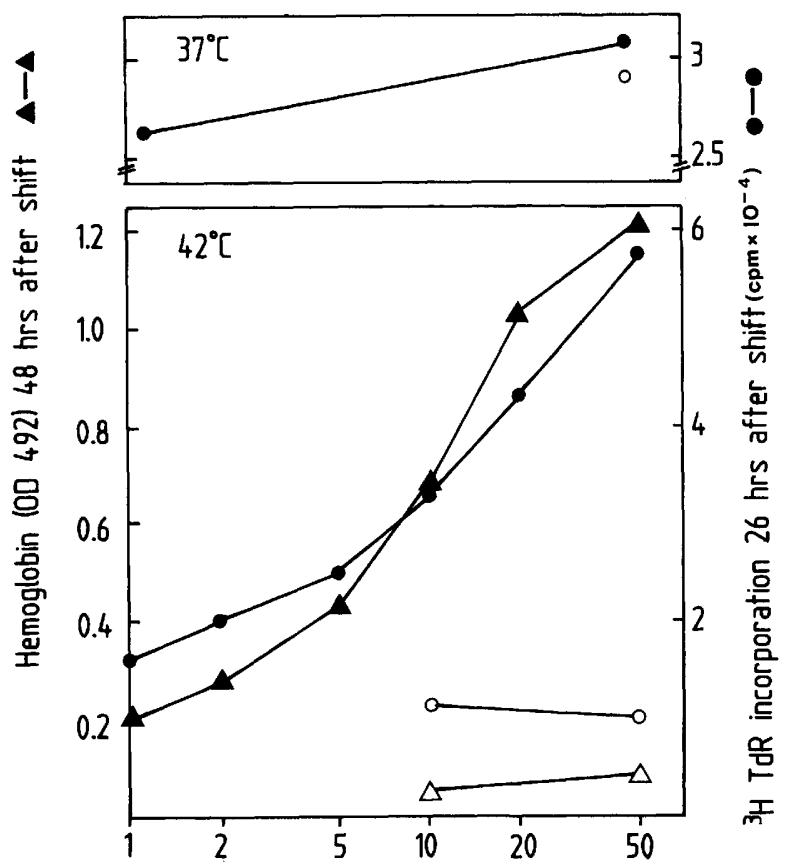

part. purified EPO $(\mu \mathrm{g} / \mathrm{ml})$ 


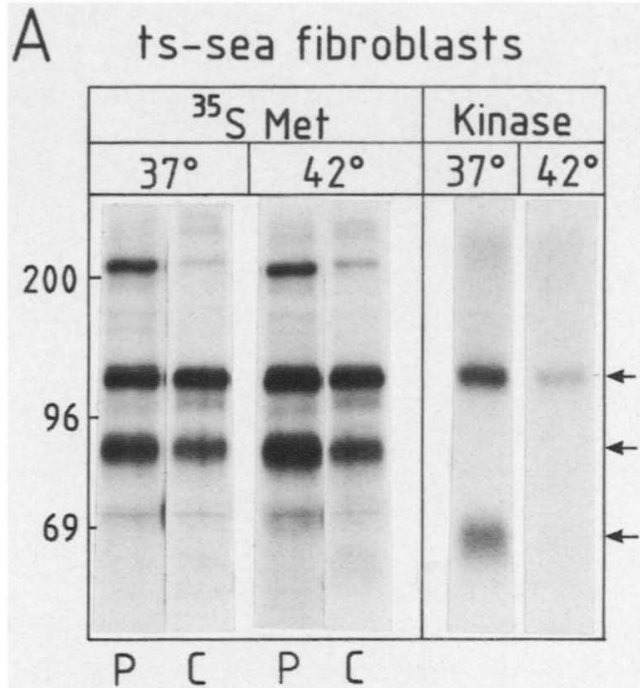

wt sea fibroblasts

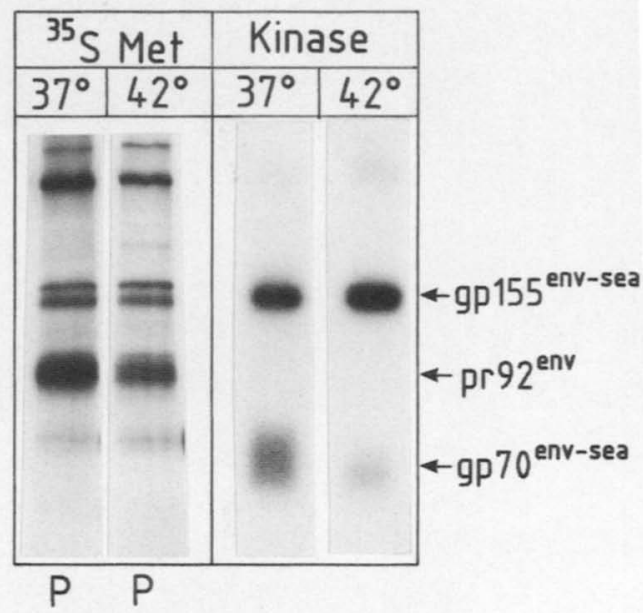

\section{ts-sea erythroblasts}
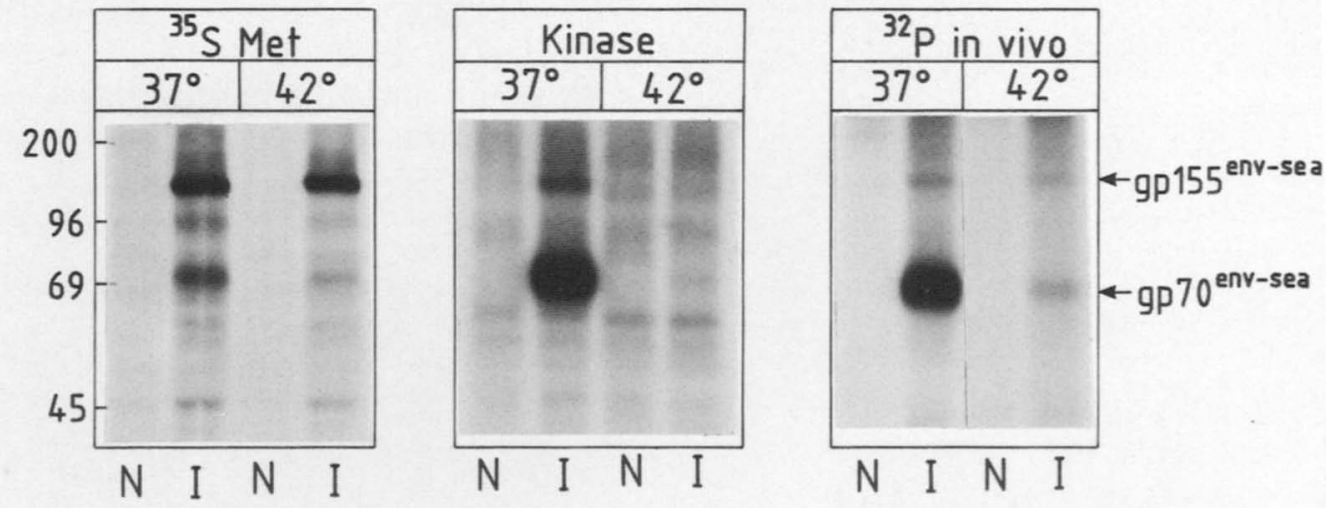

Figure 3. Tyrosine kinase activity, but not processing of the gp $155 / 70^{\text {env-sea }}$ protein is thermosensitive in $t s 1 \mathrm{~S} 13$-transformed fibroblasts and erythroblasts. (A) ts $1 \mathrm{~S} 13$ (RAV-2) (ts sea) and wt S13 (RAV-2) (wt sea) fibroblasts were grown at $37^{\circ} \mathrm{C}$ or $42^{\circ} \mathrm{C}$ for 2 days and pulse-labeled with $\left.{ }^{35} \mathrm{~S}\right]$ methionine $\left({ }^{35} \mathrm{~S} \mathrm{Met}\right)$ for $20 \mathrm{~min}(\mathrm{P})$ followed by a chase period in cold medium of $150 \mathrm{~min}(\mathrm{C})$. Aliquots of the same cells were subjected to an in vitro immune complex tyrosine kinase assay (Hayman et al. 1985). The positions of the immunoprecipitated env precursor pr92 env and of $g p 155^{\text {env-sea }}$ and $\mathrm{gp} 70^{\text {env-sea }}$ are indicated by arrows. (Left) Numbers indicate the position of molecular weight markers. In all cases, rabbit anti-gp ${ }^{e n v}$ serum was used for immune precipitation. $(B)$ ts sea erythroblasts were grown at $37^{\circ} \mathrm{C}$ in CFU-E medium or induced to differentiate for $24 \mathrm{hr}$ at $42^{\circ} \mathrm{C}$, using EPO-containing differentiation medium (see Materials and methods). Cells were then labeled for $2 \mathrm{hr}$ with $\left.{ }^{35} \mathrm{~S}\right]$ methionine $\left({ }^{35} \mathrm{~S} \mathrm{Met}\right)$ and immunoprecipitated subjected to the immune complex kinase assay (kinase) or labeled with $\left.{ }^{32} \mathrm{P}\right]$ orthophosphate $\left({ }^{32} \mathrm{P}\right.$ in vivo) immunoprecipitated. In all cases, rabbit antibody against bacterially expressed v-sea protein was used as immune serum (I), whereas normal rabbit serum was used in the controls $(\mathrm{N})$. Positions of gp $155^{\text {env-sea }}$, gp $70^{\text {env-sea }}$, and molecular-weight markers are indicated as in $A$.

pressed at the cell surface in both fibroblasts and erythroblasts after shift to the nonpermissive temperature. However, although surface expression of gp $155 / 70^{\text {env-sea }}$ remained unchanged in fibroblasts after shift to $42^{\circ} \mathrm{C}$ (Fig. 4B), a gradual decrease in its surface expression was seen in ts1 S13 erythroblasts induced to differentiate at $42^{\circ} \mathrm{C}$ (Fig. 4A). This is most likely due to the observed down-regulation of gp $155 / 70^{\text {env-sea }}$ biosynthesis in maturing erythroid cells (data not shown), which probably occurs in parallel to the general down-regulation of erythroblast glycoproteins seen previously in differentiating erythroblasts (Beug and Hayman 1984).
Erythrocyte-specific gene expression in immature,selfrenewing ts1 S13-erythroblasts before and after temperature-induced differentiation

Characterization of purified, erythroblast populations transformed by $t s 1 S 13$ or wt $S 13$ revealed that they represent immature, self-renewing cells with many properties of the late erythroid progenitor (CFU-E). During temperature-induced differentiation, they cease to express several erythroblast antigens detected by monoclonal antibodies and polyclonal antisera while starting to express several differentiation antigens characteristic 


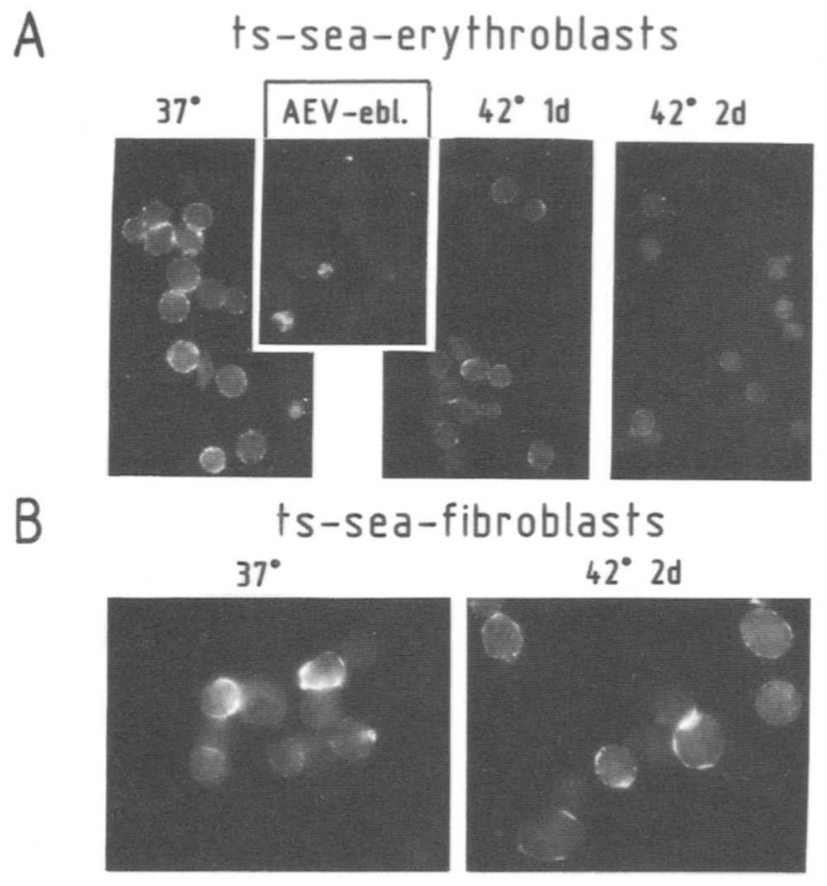

Figure 4. Cell-surface expression of the $\mathrm{S} 13$-transforming proteins is not thermosensitive. ts $1 \mathrm{~S} 13$ (ts sea)-transformed erythroblasts $(A)$ and fibroblasts $(B)$ were grown at $37^{\circ} \mathrm{C}$ or shifted to $42^{\circ} \mathrm{C}$ for the times indicated. Cells were then stained with an absorbed tumor-bearing rat antiserum to gp $155 / 70^{\text {env-sea }}$ (Hayman et al. 1985) in indirect immunofluorescence. The specificity of staining is indicated by the fact that producer erythroblasts transformed by AEV virus (AEV-ebI) are completely negative (see inset).

of erythrocytes (Schmidt et al. 1986a,b). It remained unclear, however, whether the immature cells could tolerate the expression of erythrocyte-specific proteins and how the activity of the respective genes would change during erythroid differentiation. In a first series of experiments, purified immature ts $1 \mathrm{~S} 13$ erythroblasts maintained at $37^{\circ} \mathrm{C}$ or shifted to $42^{\circ} \mathrm{C}$ for 2 days were analyzed by indirect immunofluoresence for expression of four red cell cytoskeleton proteins, namely anion transporter (band 3), band 4.1, spectrin, and an approximately $200-\mathrm{kD}$ protein recognized by the MC2.7.3 monoclonal antibody, probably representing ankyrin. This technique allows the detection of these proteins at the single cell level. Figure 5 clearly shows that most cells in the population maintained at $37^{\circ} \mathrm{C}$ already expressed all four proteins at low but clearly detectable levels. Upon shift to $42^{\circ} \mathrm{C}$, expression of band 3 and the MC2.7.3 antigen was clearly increased in essentially all cells of the population, whereas no major changes in expression were seen for band 4.1 and spectrin with this technique.

These results, showing that our cell populations were essentially homogeneous with respect to expression of the erythrocyte-specific proteins tested, encouraged us to study expression of erythrocyte-specific proteins at the biochemical level, using large-scale preparations of purified uninduced and temperature-induced ts 1 S13 cells similar to those shown in Figure 5. Aliquots of these cell preparations were then analyzed for protein expression and biosynthesis by Western blotting and immunoprecipitation of $\left.{ }^{35} \mathrm{~S}\right]$ methionine-labeled cell extracts, as well as for mRNA expression by Northern blotting. Figure $6 \mathrm{~A}$ demonstrates that the immature cells kept at $37^{\circ} \mathrm{C}$ synthesized band 3 , band 4.1 , and globin, whereas no MC2.7.3 antigen was seen (perhaps because most of the biosynthesized protein was rapidly degraded (Woods et al. 1986). After shift to $42^{\circ} \mathrm{C}$, globin, band 3, and the MC2.7.3 antigen were produced at highly increased rates, whereas no such increase was seen for band 4.1 (Fig. 6A) and spectrin (data not shown). However, the pattern of band 4.1 polypeptide synthesis changed from an immature pattern (as seen in early embryonic erythroblasts) to a mature pattern (Staufenbiel and Lazarides 1986).

A similar result (increased expression of band 3 but not of band 4.1 and spectrin) was also obtained after Western blotting of total cell extracts (Fig. 6B). However, the pattern of band-4.1 proteins present in the temperature-induced cells did not yet correspond to that found in mature erythrocytes, suggesting that 48 hours of differentiation induction were sufficient for a complete 'switch' of the biosynthetic program but not for complete replacement of immature with mature-band 4.1 polypeptides.

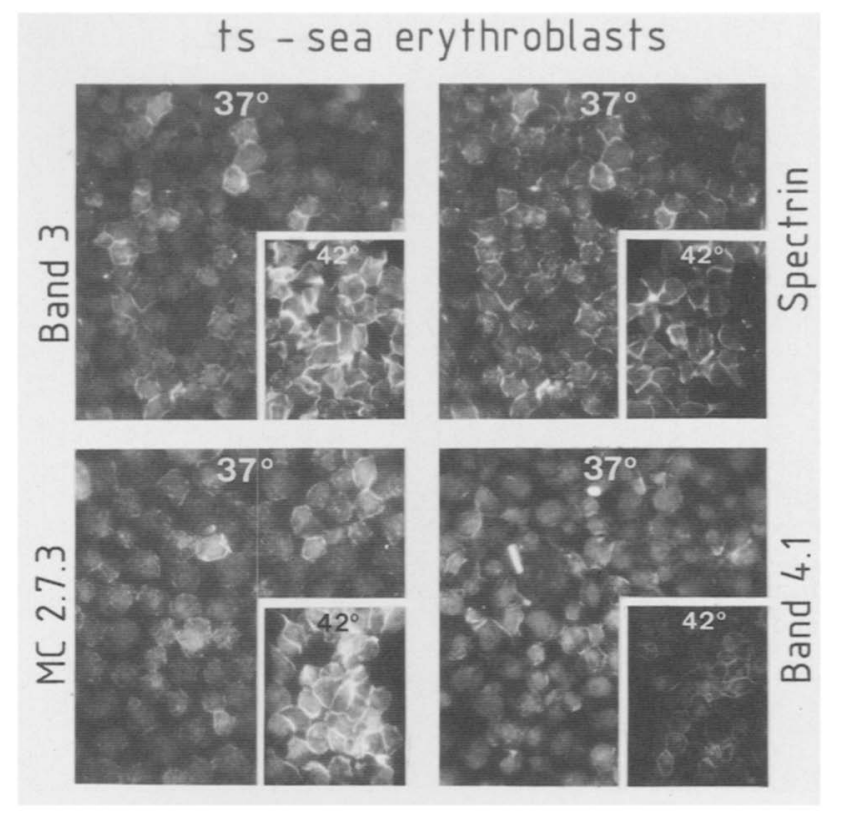

Figure 5. Detection of red cell skeleton proteins in immature, self-renewing and temperature-induced $t s 1 \mathrm{~S} 13$ erythroblasts by immunofluorescence. $t s 1 \mathrm{~S} 13$ erythroblasts (clone A4) were grown at $37^{\circ} \mathrm{C}$ or shifted to $42^{\circ} \mathrm{C}$ for $48 \mathrm{hr}$ (insets) and purified and dense cytospins were prepared (see Materials and methods). The dried cytospins were fixed, permeabilized, and stained with monoclonal antibodies to anion transporter (band 3), band 4.1, and the MC2.7.3 antigen, as well as with a polyclonal rabbit anti- $\alpha-/ \beta$-spectrin antibody. (TOp) The same fields of cells double stained with monoclonal anti-band 3 antibody and antispectrin antibody, respectively, followed by incubation with the respective fluorescein- and rhodamine-labeled second antibodies (see Beug and Hayman 1984; Materials and methods). 


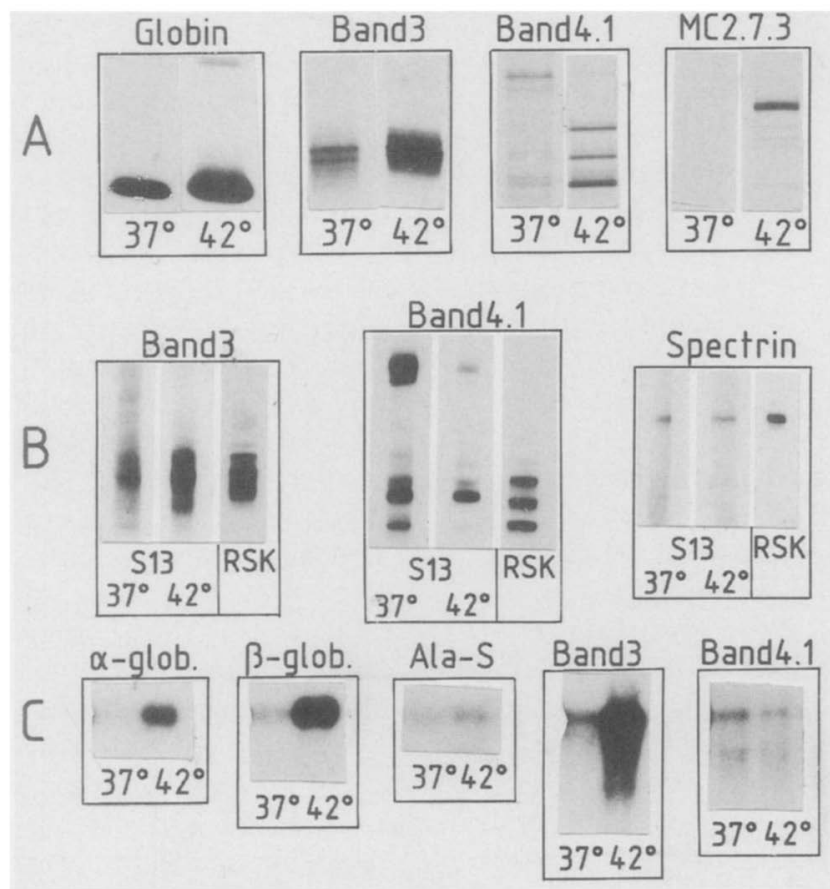

Figure 6. Expression of erythrocyte-specific proteins and their mRNAs in immature and temperature-induced $t s 1 \mathrm{~S} 13$ cells $(A)$ ts $1 \mathrm{~S} 13$ erythroblasts (clone A4) were grown at $37^{\circ} \mathrm{C}$ or shifted to $42^{\circ} \mathrm{C}$ for 2 days. After purification, cells were labeled with $\left[{ }^{35} \mathrm{~S}\right]$ methionine and subjected to immunoprecipitation analysis with monoclonal antibodies to $\alpha$ - $/ \beta$-globin, anion transporter (band 3), band 4.1, and MC2.7.3 (see Materials and methods). Fluorographs of SDS-polyacrylamide gradient gels were exposed for 1 day (globin), 4 days (band 3), and 12 days (MC2.7.3, band 4.1.). Note the different variants of the band-4.1 protein occurring in immature and differentiated cells (Staufenbiel and Lazarides 1986). $(B)$ Uninduced and temperature-induced $t s 1$ S13 (S13) cells were lysed in SDS-PAGE sample buffer and subjected to Western blot analysis as described in Materials and methods. As controls, purified preparations of red cell membranes (RSK) were run in parallel. $(C)$ Total RNA was extracted from $4 \times 10^{7}$ to $6 \times 10^{7}$ uninduced and temperature-induced $t s 1$ S13 cells prepared as in $A$. After electrophoresis in agarose gels (10 $\mu \mathrm{g}$ RNA/lane) and blotting to gene screen membrane, RNAs were hybridized to labeled probes specific for the genes indicated (see Materials and methods). Blots were exposed to film for $6 \mathrm{hr}$ (band 3), $16 \mathrm{hr}$ (band 4.1), $16 \mathrm{hr}$ (Ala S), and $2 \mathrm{hr}$ ( $\alpha$ and $\beta$-globin).

The protein data indicating that immature, self-renewing $t s 1 \mathrm{~S} 13$ erythroblasts already express a variety of erythrocyte-specific genes at relatively low level, some of which are markedly up-regulated during temperatureinduced differentiation, were confirmed and extended by Northern blot analysis of total RNA. ts 1 S13 cells kept at $37^{\circ} \mathrm{C}$ expressed detectable levels of mRNA specific for $\alpha$ - and $\beta$-globin, band $3, \mathrm{Na}^{+} \mathrm{K}^{+}$ATPase, band 4.1, $\beta$ actin and Ala S ( $\delta$-aminolevulinic acid synthetase, a key enzyme in hemin biosynthesis). Upon shift to $42^{\circ} \mathrm{C}$, steady-state levels of mRNA for both globins, anion transporter, and Ala S showed a marked increase, whereas no such changes were seen for $\mathrm{Na}^{+} \mathrm{K}^{+}$ATPase, band 4.1, and $\beta$-actin. (Fig. $6 \mathrm{C}$ and data not shown). Nuclear run-on analysis confirmed that up-regulation of the globin, anion transporter, and Ala $\mathrm{S}$ genes occurred at the transcriptional level (data not shown).

The results shown so far do not resolve the question of whether the observed low-level expression of erythrocyte-specific genes in transformed, self-renewing ts $1 \mathrm{~S} 13$ erythroblasts is a trait of normal erythroid progenitors or an aberrant phenomenon due to the transformed state of the cells. Because normal erythroid progenitors in numbers sufficient for such studies cannot be isolated, we addressed this question in an indirect manner. Based on the assumption (found to be true for other temperature-sensitive kinase oncogenes such as $t s \mathrm{src}$ ) that the gp155/70 env-sea associated kinase activity in ts 1 S13 erythroblasts is destroyed within a few hours after shift to $42^{\circ} \mathrm{C}$, we analyzed these cells for early changes in erythrocyte gene expression, which would precede upregulation of gene expression due to the onset of differentiation. The results shown in Figure 7 clearly show that low-level expression of mRNA for $\beta$-globin, band 3 , and Ala $\mathrm{S}$ persisted during the first 5 hours after shift, although some reduction in expression level was visible for Ala $\mathrm{S}$ and perhaps band-3 mRNA. In contrast, expression of mRNA for carbonic anhydrase (expression of which is only turned on late during mouse erythropoiesis; Conscience et al. 1987) was down-regulated to very low levels within 5 hours, indicating that this gene is

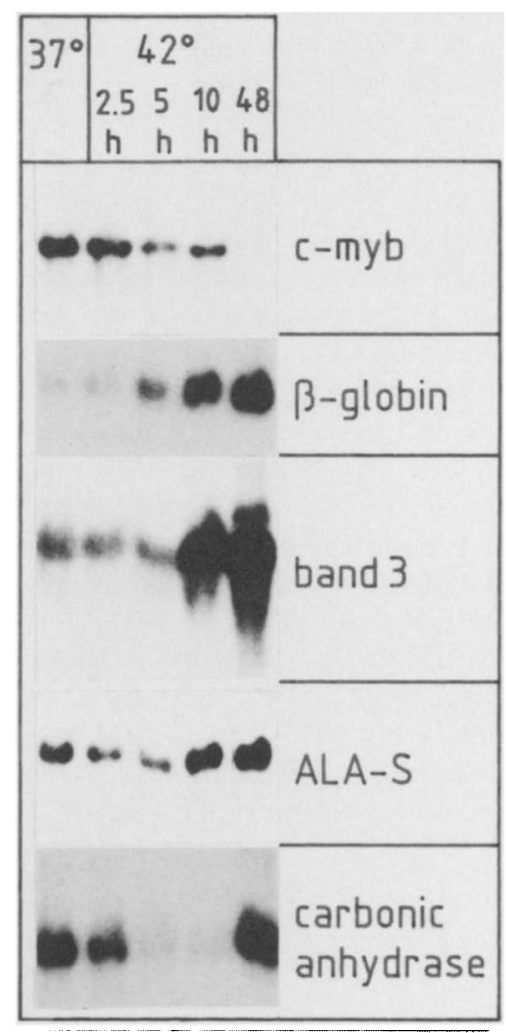

Figure 7. Kinetics of erythrocyte-specific RNA expression shortly after shift to $42^{\circ} \mathrm{C}$. ts $1 \mathrm{~S} 13$ erythroblasts were grown at $37^{\circ} \mathrm{C}$ or shifted to $42^{\circ} \mathrm{C}$ for $2.5 \mathrm{hr}(2.5 \mathrm{~h}), 5 \mathrm{hr}, 10 \mathrm{hr}$, or 2 days. Extraction of RNA and Northern blot analysis was performed as described in the legend to Fig. 6. Exposure of the film showing the carbonic anhydrase RNA was for 5 days. 
aberrantly expressed in the transformed cells and confirming that the cells 'normalize' to some extent before up-regulation of gene expression due to maturation, which occurred after 10 hours for globin, band 3, and Ala $\mathrm{S}$ and only after 48 hours for carbonic anhydrase. Taken together, these data confirm our earlier notion, that $t s 1$ S13 erythroblasts resemble normal erythroid progenitors in many respects, but in addition, exhibit aberrant features, such as elevated or even asynchronous expression of erythroid differentiation markers (Schmidt et al. 1986a,b). Upon shift to $42^{\circ} \mathrm{C}$, however, these aberrant features are rapidly lost, suggesting that erythroid differentiation in the temperature-sensitive $\mathrm{S} 13$ system starts from essentially normal progenitor like cells.

\section{Discussion}

The thermosensitive lesion in gp155/70 env-sea affects its autophosphorylation on tyrosine in vitro and in vivo

In this paper we have described the isolation and characterization of a mutant of the S13 virus (ts $1 \mathrm{~S} 13$ ) that is temperature sensitive for transformation of both fibroblasts and erythroblasts. Our results demonstrate that the temperature-sensitive lesion in the transforming protein of this mutant (gp155/70 env-sea $)$ affects its kinase activity, the autophosphorylation of this protein being thermolabile both in an in vitro immune-complex assay and after ${ }^{32} \mathrm{P}$-labeling of intact cells. However, neither cleavage of the gp $155^{\text {env-sea }}$ precursor into gp $70^{\text {env-sea }}$ and gp $85^{e n v}$ nor its maturation and insertion into the plasma membrane were grossly affected by the temperaturesensitive lesion. Thus, the $t s 1 \mathrm{~S} 13$-transforming protein represents a thermolabile tyrosine kinase similar to those found in temperature-sensitive-v-src and temperature-sensitive $\mathrm{v}$-fps mutants of Rous sarcoma virus (RSV) and Fujinami sarcoma virus (FSV). The temperature-sensitive sea protein, however, is distinct from the temperature-sensitive-er $b B$ proteins of $t s 34$ and $t s 167$ AEV (Graf et al. 1978; Palmieri et al. 1982; Beug and Hayman 1984); the temperature-sensitive lesion of which affects glycoprotein maturation and plasma membrane localization but not its associated kinase activity (Hayman et al. 1986).

Although our data indicate that the tyrosine kinase activity of the env-sea protein of $S 13$ virus is required for transformation, it remains an open question whether or not both forms of this protein, gp $155^{\text {env-sea }}$ and $\mathrm{gp} 70^{\text {env-sea, }}$ are transforming.

Temperature-sensitive sea-transformed erythroblasts: An improved cell system to study erythroid differentiation

Although erythroblasts transformed by the available temperature-sensitive AEV mutants have proved a valuable system to study erythroid differentiation, the $t s 1$ S13-transformed erythroblasts described here appear to be far better suited to mimic the differentiation of normal erythroid progenitors because of two recent findings. First, the v-erbA protein of temperature-sensitive AEV mutants, v-erbA, causes a transcriptional arrest of expression of several erythrocyte-specific genes, which can be partially overcome by use of special culture conditions (Beug et al. 1982; Beug and Hayman 1984; M. Zenke et al., in press). Furthermore, the erbB proteins of both ts 34 and ts 167 AEV display a distinct, residual transforming activity at nonpermissive temperature in both fibroblasts and erythroblasts (Beug and Graf 1980; Palmieri et al. 1982; H. Beug et al., unpubl.). Because it has been much easier to induce transformed erythroid colonies with ts $1 \mathrm{~S} 13$ than with the other available temperature-sensitive kinase mutants of RSV and FSV (Kahn et al. 1984; H. Beug, unpubl.), the latter viruses also do not seem to represent a reasonable alternative to $t s 1 \mathrm{~S} 13$.

As in any other in vitro cell system employing differentiation-inducible, but transformed erythroid cells, it is clear that differentiation in the temperature-sensitive S13 cell system starts from self-renewing, partially aberrant erythroblasts rather than from normal erythroid progenitors that do not self-renew. Although this fact requires that any conclusions derived from the temperature-sensitive $\mathrm{S} 13$ system can only be applied to normal erythropoiesis with caution, the available data suggest that due to the rapid and fairly complete thermal inactivation of the transforming oncogene, few if any traits of the transformed cell persist during temperature-induced differentiation of the $t s 1 \mathrm{~S} 13$ erythroblasts.

Erythrocyte-specific gene expression during self-renewal and differentiation of ts 1 S13-transformed erythroblasts

Leukemic transformation of avian erythroid cells by a variety of tyrosine kinase as well as non-kinase oncogenes, such as v-H-ras, is characterized by induction of continous self-renewal of the infected, immature progenitor cells (Graf et al. 1976; Beug et al. 1985a). It was therefore surprising that these self-renewing, leukemic cells already expressed low levels of most if not all erythrocyte-specific proteins. This result suggests that the proliferation of transformed erythroid progenitors is compatible with low-level expression of several major erythrocyte proteins that are characterisitic of the mature postmitotic erythrocyte. Therefore, induction of self-renewal by these oncogenes does not lead to a complete block of erythrocyte-specific gene expression but may only require that these genes are not expressed at levels exceeding those of the housekeeping proteins, which are characteristic of immature, proliferating cells. According to this concept, only quantitative (perhaps even small) changes in the relative rates of synthesis of these two types of molecules might be required to convert a normal, maturing progenitor into a self-renewing leukemic cell.

The second conclusion suggested by our studies is that some erythrocyte proteins such as the globins, anion transporter, Ala-S, carbonic anhydrase, and the MC2.7.3 antigen are drastically up-regulated relatively 
late in erythroid differentiation, whereas the expression of other erythrocyte proteins, for example, band 4.1 and spectrin, is not controlled in this way. Alternatively, expression of the former proteins might already be high in the normal progenitors representing the target cells for leukemic transformation. If this is correct, the main effect of the transforming oncogene would be to reduce, but not to abolish, expression of certain erythrocyte-specific genes.

Recently, it has been suggested that erythroid differentiation is regulated by late, asynchronous expression of the anion transporter (Woods et al. 1986). However, the absence of anion transporter in AEV-transformed erythroblasts observed by Woods et al. appears to be due to the presence of the erbA oncogene in these cells $(\mathrm{M}$. Zenke et al., unpubl.). The apparent discrepancy between our results on anion transporter expression in S13-transformed erythroblasts and those obtained by Woods et al. (1986) is not easily explained at present and will merit further experimentation. The data presented in this paper do not strongly support the idea of the anion transporter playing a crucial regulatory role in early stages of erythroid differentiation, as it is already expressed in immature erythroblasts. However, it is certainly possible that the anion transporter does play a pivotal role in the assembly of the erythrocyte differentiation as well as for structure and function of the mature red blood cell.

\section{Outlook}

The experiments described herein using tsl S13-transformed erythroblasts demonstrate the usefulness of this new system to study gene expression during erythroid differentiation. It was found that erythrocyte-specific genes are not expressed as a coordinate group of genes and that the expression of these gene products typical for mature, postmitotic cells is not incompatible with cell growth. The temporal regulation of genes such as band 3 and MC2.7.3 contrasts markedly with the regulation of expression of the various forms of the band-4.1 proteins and demonstrates the potential of this system for unraveling the complexities of cytoskeleton assembly and erythroid differentiation.

\section{Materials and methods}

Virus strains

The origin and characterization of the S13 virus has been described earlier (Benedict et al. 1985; Beug et al. 1985b). The $t s 1$ S13 virus substrain was isolated from a nonproducer erythroblast clone (clone 9; Beug et al. 1985b) superinfected with RAV-1, whereas the wt S13 strain has been cloned in nonproducer fibroblasts (P. Vogt, unpubl.) superinfected with RAV-1.

\section{Cells and cell culture}

ts 1 S13 and wt S13 erythroblast clones were produced by seeding infected bone marrow cells into semisolid medium (Methocel) and isolation of transformed colonies 6-8 days later
(Beug et al. 1985b). Unless stated otherwise, all cell clones were propagated in CFU-E medium without anemic chicken serum (Radke et al. 1982; Beug and Hayman 1984). Well-differentiating $t s 1 \mathrm{~S} 13$ erythroblast clones exhibiting long $\mid>40$ generations) in vitro life spans were selected from over 100 individual colonies, as described earlier (Beug and Hayman 1984; Kowenz et al. 1987).

CEFs transformed by $t s 1 \mathrm{~S} 13$ and wt $\mathrm{S} 13$ viruses were produced by cocultivating CEFs freshly prepared from 11-day-old chick embryos (Graf 1973) with the respective virus-producing erythroblasts for 2 days (Beug et al. 1986). Both infected and uninfected fibroblasts were grown in standard growth medium (Dulbecco's modified Eagle's medium (DMEM) plus $8 \%$ fetal calf serum, $2 \%$ chicken serum, and 25 mM HEPES, pH7.3).

Large-scale temperature induction of erythroid differentiation in temperature-sensitive $\$ 13$ erythroblasts

Prior to differentiation induction, $t s 1 \mathrm{~S} 13-$ and $w t$ S13-transformed erythroblasts were separated from spontaneously differentiating cells by purification on Percoll step gradients /using only cells with a density of $\left.\leqslant 1.070 \mathrm{~g} / \mathrm{cm}^{3}\right)$. The cells were then seeded at $1 \times 10^{6}$ to $1.5 \times 10^{6}$ cells into a modified differentiation medium (Kowenz et al. 1987) supplemented with $150 \mu \mathrm{l}$ EPO (high-titer anemic chicken serum prepared according to Kowenz et al. 1987), $5 \mu$ l of partially purified erythroid growth factor produced by an avian reticuloendotheliosis virus (REV-T) transformed lymphoblast cell line (M. Zenke et al., in prep.), and $6 \mu \mathrm{l}$ insulin $(1.7 \mathrm{mg} / \mathrm{ml}$, Actrapid, Bayer, Leverkusen, Germanyl per $10 \mathrm{ml}$ of medium and incubated at $42^{\circ} \mathrm{C}$ and $5 \% \mathrm{CO}_{2}$. Cell density was kept between $1 \times 10^{6}$ to $2 \times 10^{6}$ cells $/ \mathrm{ml}$ by addition of the above medium, and a partial medium change was performed daily. Because of the relative homogeneity of the differentiated cell populations, it was sufficient to remove dead or malformed cells by centrifugation through Ficoll $137^{\circ} \mathrm{C}$ and $12-24 \mathrm{hr}$ at $\left.42^{\circ} \mathrm{C}\right)$, Percoll $1.072 \mathrm{~g} / \mathrm{cm}^{3}\left(48 \mathrm{hr}\right.$ at $\left.42^{\circ} \mathrm{C}\right)$, or Percoll $1.080 \mathrm{~g} / \mathrm{cm}^{3}\left(72 \mathrm{hr}\right.$ at $42^{\circ} \mathrm{C}$; Beug et al. 1982; Schmidt et al. $1986 \mathrm{~b}, \mathrm{c})$. Control cells grown at $37^{\circ} \mathrm{C}$ were purified on Percoll $1.070 \mathrm{~g} / \mathrm{cm}^{3}$ as described above.

Assays for stimulation of proliferation and hemoglobin production of temperature-sensitive $S 13$ cells by EPO

These assays have been described elsewhere (Kowenz et al. 1987).

\section{Assays for fibroblast transformation parameters}

ts 1 S13- and wt S13-transformed fibroblasts were cultivated at $37^{\circ} \mathrm{C}$ or $42^{\circ} \mathrm{C}$ for at least $24 \mathrm{hr}$. They were then assayed for morphology, actin filament cables, fibronectin expression, and uptake of $\left[{ }^{3} \mathrm{H}\right] 2$-deoxyglucose, as described earlier (Royer-Pokora et al. 1978; Palmieri et al. 1982). Agar colony formation of virus-infected, primary fibroblasts was assayed as described elsewhere (Jansson et al. 1987).

Assay of differentiating ts1 S13 erythroblasts for morphology, hemoglobin, content, and size

Cytospin preparations of ts $1 \mathrm{Sl} 3$ erythroblasts were stained with neutral benzidine plus histological dyes (Diff-Quik, Harleco, Amsterdam), as described earlier (Beug et al. 1982). Size distribution was measured using a Coulter counter connected to a multichannel analyzer $(32$ channels, constructed in the EMBL). Under the particular conditions used, chick erythrocytes (mean diam. $5 \mu \mathrm{m}$ ) band at channel 4 , whereas trans- 
formed erythroblasts (mean diam. $12 \mu \mathrm{m}$ ) band at channels $18-22$.

\section{Antisera}

The following antibodies to erythrocyte-specific proteins were used: MC4.2.A.5, a monoclonal antibody reacting with embryonic and adult chicken hemoglobins (Hayman et al. 1982); MCA2E, a monoclonal antibody to the chicken anion transporter (Yew et al. 1987); MC3C, a monoclonal antibody to chicken band 4.1 (Yew et al. 1987); MC2.7.3, a monoclonal antibody directed against a $\sim 200-\mathrm{kD}$ red cell skeleton protein $/ \mathrm{a}$ kind gift of $\mathrm{H}$. Weintraub, Seattle); and a polyclonal rabbit antiserum to $\alpha$-/ $\beta$-spectrin (J.D. Engel et al., unpubl.). The $\sim 200-$ $\mathrm{kD}$ protein detected by the MC2.7.3 antibody might represent ankyrin, because it is present in large amounts in purified red cell skeleton preparations but differs from $\alpha-\beta$-spectrin both in mobility on gels and in its expression during temperature-induced differentiation (H. Beug and M.J. Hayman, unpubl.). Antisera to the $\mathrm{gp} 155 / 70^{\text {env-sea }}$ protein of $\mathrm{S} 13$ virus were anti-gp $\mathrm{p}^{\text {env }}$ serum (Hayman et al. 1979), tumor-bearing rat antisera (Hayman et al. 1985), and a rabbit antiserum to a v-sea polypetide expressed in bacteria (J. Knight et al., unpubl.).

\section{Immunofluorescence}

Staining of live, transformed fibroblasts with a tumor-bearing rat antiserum detecting S13-specific env determinants at the cell surface was performed as described earlier (Hayman et al. 1985).

Dense cytospin preparations $\left(3 \times 10^{5}\right.$ to $4 \times 10^{5}$ cells/ sample) were prepared as described earlier (Beug et al. 1982) and air dried. They were fixed in $3.7 \%$ formaldehyde at $4^{\circ} \mathrm{C}$ for 30 min, washed once each in PBS and DMEM plus $10 \%$ fetal calf serum and $25 \mathrm{~mm}$ HEPES ( $\mathrm{pH} 7.3$ ), permeabilized for $15 \mathrm{~min}$ in the above medium also containing $0.1 \%$ NP-40, and washed twice with phosphate-buffered saline (PBS) plus $0.2 \%$ gelatin and $0.5 \%$ bovine serum albumin (BSA). The fixed cytospin preparations were then stained with anti-erythrocyte cytoskeleton antibodies in double immunofluorescence, as described earlier (Beug et al. 1979; Beug and Hayman 1984), using fluorescein isothiocyanate (FITC)-conjugated goat anti-mouse $\mathrm{Fab}_{2}$ (Medac, Hamburg, Germany, 1:30) and Texas-red conjugated goat anti-rabbit IgG (Amersham-Buchler, $1: 30$ ).

\section{Immunoprecipitation analysis}

Labeling of purified cell populations with $\left[{ }^{35} \mathrm{~S}\right]$ methionine and immunoprecipitation analysis was done as described earlier (Hayman et al. 1983; Beug and Hayman 1984), except for the following modifications: For immunoprecipitation of gp155/ $70^{\text {env-sea, }}$ globin, and band 3, cells were lysed in detergent-containing lysis buffer as described (Hayman et al. 1979, 1983). Immunoprecipitation of the $\mathrm{MC2.7.3}$ antigen and band 4.1 was performed after lysis of $10 \times 10^{6}$ cells in $0.1 \mathrm{ml} 2 \% \operatorname{SDS} / 15^{\prime}$ $37^{\circ} \mathrm{C}$, dilution with $1.9 \mathrm{ml}$ of the above lysis buffer, and centrifugation $(20,000 \mathrm{~g}, 30 \mathrm{~min})$. For immunoprecipitation with monoclonal antibodies, the Staphylococcus aureus preparations used to collect the immune complexes were preincubated for $30 \mathrm{~min}$ with $10 \mu \mathrm{g}$ of affinity-purified rabbit anti-mouse IgG per $30 \mu \mathrm{l}$ of $10 \%$ Staph A suspension. Immunoprecipitated proteins were analyzed by SDS-polyacrylamide electrophoresis and fluorography (Beug et al. 1981; Beug and Hayman 1984), using $6-12 \%$ gradient gels for all proteins except globin, where $6-20 \%$ gradient gels were used.
Western blotting analysis

Analysis of red cell cytoskeleton proteins was performed as described elsewhere (Leutz et al. 1987), using purified avian red cell membranes (D. Engel, unpubl.) as standards. Briefly, cells were lysed in SDS-PAGE sample buffer at $1 \times 10^{8} \mathrm{cells} / \mathrm{ml}$ and equal aliquots run on a $6-12 \%$ denaturing gel. Proteins were transferred to nylon membranes (BioRad) and reacted with antibodies plus ${ }^{125}$ I-labeled protein A as described in Leutz et al. (1987). When monoclonal antibodies were used, the membranes were reacted with affinity-purified rabbit anti-mouse IgG antibody prior to application of ${ }^{125}$-labeled protein $\mathrm{A}$.

\section{${ }^{32} \mathrm{P}$ labeling of S13-transformed cells and in vitro tyrosine kinase assay of $g p 155 / 70^{\text {env-sea }}$}

The in vitro immune complex kinase assays were performed as described elsewhere (Hayman et al. 1985, 1986). For labeling with ${ }^{32} \mathrm{P}$-labeled $\mathrm{PO}_{4}$, approximately $2 \times 10^{7}$ cells were labeled for $4 \mathrm{hr}$ with $1 \mathrm{mCi}$ [ ${ }^{32} \mathrm{P}$ ]orthophosphate per $\mathrm{ml}$ of phosphatefree DMEM supplemented with $2 \%$ dialyzed fetal calf serum. The cells were then lysed in $10 \mathrm{mM}$ HEPES (pH 7.3), 10\% glycerol, $150 \mathrm{mM} \mathrm{NaCl}, 50 \mu \mathrm{M} \mathrm{Na}$ orthovanadate, and $0.1 \%$ Triton $\mathrm{X}-100$ and immunoprecipitated as described above.

For quantitative evaluation, the gel autoradiographs were scanned, and the peak area determined by cutting out the peaks from the paper strip and weighing, using a microbalance. Because of the relatively high background of the gels (Fig. 3B,C), lower limits of the differences (>20-fold) are given in the text rather than the exact figures.

\section{RNA preparation and Northern blot analysis}

Total RNA has been prepared using the guanidinium thiocyanate/CsCl step gradient procedure (Glisin et al. 1974; Maniatis et al. 1982) with the modification that a mixture of $50 \mathrm{~mm}$ Tris- $\mathrm{HCl}(\mathrm{pH} 7.5), 5 \mathrm{~mm}$ EDTA, and $1 \%$ sarkosyl was used to dissolve the RNA after $\mathrm{CsCl}$ step gradient centrifugation and for subsequent extractions.

After gel electrophoresis ( $1 \%$ agarose) in $0.2 \mathrm{M}$ formaldehyde (Lehrach et al. 1977; Maniatis et al. 1982) the RNA (10-20 $\mu \mathrm{g}$ ) was blotted to GeneScreen membrane (NEN) in 20× SSC and cross-linked by UV treatment. Hybridization with $\alpha\left[{ }^{32} \mathrm{P}\right] \mathrm{dCTP}-$ labeled probes, prepared by nick-translation (Rigby et al. 1977), was performed in $45 \%(\mathrm{vol} / \mathrm{vol})$ formamide, $0.2 \mathrm{M} \mathrm{Na}$ phosphate (pH 7.2), $1 \mathrm{~mm}$ EDTA, 7\% SDS, $100 \mu \mathrm{g} / \mathrm{ml}$ denatured salmon sperm DNA, $10^{6} \mathrm{cpm} / \mathrm{ml}$ at $42-45^{\circ} \mathrm{C}$ for $16 \mathrm{hr}$. The membranes were subsequently washed in $40 \mathrm{~mm} \mathrm{Na}$ phosphate (pH 7.2) and $1 \%$ SDS at $55-65^{\circ} \mathrm{C}$ for $1-2 \mathrm{hr}$. The recombinant DNAs used for probe preparation by nick-translation were as follows: (band 3) pcB3 2.0 and pcB3 3.1 containing 2.0 and $3.1 \mathrm{~kb}$, respectively, of chicken erythroid band 3-specific cDNA sequences ( $M$. Zenke et al., in prep.); (band 4.1 ) p4.1A, bearing $1.9 \mathrm{~kb}$ of chicken band 4.1 cDNA in pGEM2 (Yew et al. 1987); ( $\beta$-globin) pblBR 15, containing the entire chicken $\beta$-globin gene (Dolan et al. 1983); $(\beta$-actin) pbA13, which contains $2 \mathrm{~kb}$ of chicken cytoplasmic $\beta$-actin cDNA in the HindIII site of pSP64 (Cleveland et al. 1980); (carbonic acid anhydrase) pCA-1.2, containing 1.2 $\mathrm{kb}$ of chicken carbonic anhydrase II cDNA (Yoshihara et al. 1987).

The Ala $S$ probe used was an $[\alpha-32$ P $]$ GTP-labeled transcript from the SP6 promoter of recombinant pA4d, containing a 775bp cDNA insert in the EcoRI site of pGEM1 (Yamamoto et al. 1985). Hybridization conditions were the same as for nicktranslated probes, except that the hybridization temperature was $65^{\circ} \mathrm{C}$. After hybridization, the membrane was treated with 
RNase A $(5 \mu \mathrm{g} / \mathrm{ml})$ in $2 \times \mathrm{SSC}$ at $37^{\circ} \mathrm{C}$ for $30 \mathrm{~min}$ following washing, as described above.

\section{Acknowledgments}

This work was supported, in part, by U.S. Public Health Service grants to M.J.H., P.K.V., and J.D.E. and a NATO collaborative research grant to H.B. and M.J.H.; and grant 1951 from the Council for Tobacco Research to P.K.V.

\section{References}

Benedict, S.H., Y. Maki, and P.K. Vogt. 1985. Avian retrovirus S13: Properties of the genome and of the transformationspecific protein. Virology 145: 154-164.

Beug, H. and T. Graf. 1980. Transformation parameters of chicken embryo fibroblasts infected with ts 34 mutant of avian erythroblastosis virus. Virology 100: $348-356$.

Beug, H. and M.J. Hayman. 1984. Temperature-sensitive mutants of avian erythroblastosis virus: Surface expression of the erbB product correlates with transformation. Cell 36: 963-972.

Beug, H., T. Graf, and M.J. Hayman. 1981. Production and characterization of antisera specific for the erb-portion of $\mathrm{p} 75$, the presumptive transforming protein of avian erythroblastosis virus. Virology 111: 201-210.

Beug, H., M.J. Hayman, M.B. Raines, H.J. Kung, and B. Vennstrom. 1986. RAV-1 induced erythroleukemic cells exhibit a weakly transformed phenotype in vitro and release c-erbB containing retrovinuses unable to transform fibroblasts. $J$. Virology 57: 1127-1138.

Beug, H., P. Kahn, G. Döderlein, M.J. Hayman, and T. Graf. 1985a. Characterization of hematopoietic cells transformed in vitro by $\mathrm{AEV}-\mathrm{H}$ and erbB-containing avian erythroblastosis virus. In Modern trends in leukemia VI (ed. R. Neth, R. Gallo, M. Greaves, and K. Janka), Springer Verlag, Heidelberg, pp. 290-297.

Beug, H., S. Palmieri, C. Freudenstein, H. Zentgraf, and T. Graf. 1982. Hormone-dependent terminal differentiation in vitro of chicken erythroleukemia cells transformed by ts mutants of avian erythroblastosis virus. Cell 28: 907-919.

Beug, H., A. von Kirchbach, G. Döderlein, J.F. Conscience, and T. Graf. 1979. Chicken hematopoietic cells transformed by seven strains of defective avian leukemia viruses display three distinct phenotypes of differentiation. Cell 18: 375390.

Beug, H., M.J. Hayman, T. Graf, S.H. Benedict, A.M. Wallbank, and P.K. Vogt. 1985b. S13, a rapidly oncogenic replicationdefective avian retrovirus. Viroloy 145: 141-153.

Blau, H.M., G.K. Pavlath, E.C. Hardeman, C.P. Chin, L. Siberstein, S.G. Webster, S.C. Miller, and C. Webster. 1985. Plasticity of the differentiated state. Science 230: 758-766.

Blikstad, I., W.J. Nelson, R.T. Moon, and E. Lazarides. 1983. Synthesis and assembly of spectrin during avian eythropoiesis, stoichiometric assembly but unequal synthesis of $\alpha$ and $\beta$ spectrin. Cell 32: 1081-1091.

Bonanov-Tzedaki, S.A., M. Sohi, and H.R.V. Arnstein. 1981. Regulation of erythroid cell differentiation by hemin. Cell. Diff. 10: 267-279.

Choi, O.R. and J.D. Engel. 1986. A 3' enhancer is required for temporal and tissue-specific transcriptional activation of the chicken adult $\beta$-globin gene. Nature 323: 731-734.

Choi, O.R., C. Trainor, T. Graf, H. Beug, and D. Engel. 1986. A single amino acid substitution in v-erbB confers a thermolabile phenotype to ts167 AEV-transformed erythroid cells. Mol. Cell. Biol. 6: 1751-1759.
Cleveland, D.W., M.A. Lopate, R.J. McDonald, N.J. Cowan, W.J. Rutter, and M.W. Kirschner. 1980. Number and evolutionary conservation of $\alpha$ and $\beta$-tublin and cytoplasmic $\beta$ and $\lambda$-actin genes using specific cloned cDNA probes. Cell 20: $95-105$.

Conscience, J.F., R.A. Miller, I. Henry, and H. Ruddle. 1987. Acetylcholinesterase, carbonic anhydrase and catalase activity in Friend erythroleukemia cells and nonerythroid mouse cell lines. Exp. Cell Res. 105: 401-412.

Dolan, M., J.B. Dodgson, and J.D. Engel. 1983. Analysis of the adult chicken $\beta$-globin gene. J. Biol. Chem. 258: 3983-3990.

Emerson, B.M., C.D. Lewis, and G. Felsenfeld. 1985. Interaction of specific nuclear factors with the nuclease-hypersensitive region of the chicken adult $\beta$-globin gene: Nature of the binding domain. Cell 41: 21-30.

Falcone, G., D. Boettiger, S. Alema, and F. Tato. 1984. Role of cell division in differentiation of myoblasts infected with a temperature-sensitive mutant of Rous sarcoma virus. EMBO I. 3: 1327-1331.

Glisin, V., D. Crkvenjakov, and C. Buys. 1974. Ribonucleic acid isolated by cesium chloride centrifugation. Biochemistry 13: $2633-2642$.

Graf, T. 1973. Two types of target cells for transformation with avian myelocytomatosis virus. Virology 54: 398-413.

Graf, T., N. Ade, and H. Beug. 1978. Temperature-sensitive mutant of avian erythroblastosis virus suggests a block of differentiation as mechanism of leukaemogenesis. Nature 257: 496-501.

Graf, T., B. Royer-Pokora, G.E. Schubert, and H. Beug. 1976. Evidence for the multiple oncogenic potential of cloned leukemia virus: In vitro and in vivo studies with avian erythroblastosis virus. Virology 71: 423-433.

Harrison, P.R. 1984. Molecular analysis of erythropoiesis. A current appraisal. Exp. Cell Res. 155: 321-344.

Hayman, M.J., H. Beug, and K. Savin. 1982. Changes in the expression of membrane antigens during the differentiation of erythroid precursor cells in vitro. J. Cell. Biochem. 18: 351362.

Hayman, M.J., B. Royer-Pokera, and T. Graf. 1979. Defectiveness of avian erythroblastosis virus: Synthesis of a $75 \mathrm{~K}$ gagrelated protein. Virology 92: 31-45.

Hayman, M.J., G. Kitchener, P.K. Vogt, and H. Beug. 1985. The putative transforming protein of $\mathrm{S} 13$ avian erythroblastosis virus is a transmembrane glycoprotein with associated protein kinase activity. Proc. Natl. Acad. Sci. 82: 8237-8241.

Hayman, M.J., G. Kitchener, J. Knight, J. McMahon, R. Watson, and H. Beug. 1986. Autophosphorylation of $v$-erbB does not correlate with cell transformation. Virology 150: 270-275.

Hayman, M.J., G.M. Ramsay, K. Savin, G. Kitchener, T. Graf, and $H$. Beug. 1983. Identification and characterization of the avian erythroblastosis virus, $e r b B$ gene product as a membrane glycoprotein. Cell 32: 579-588.

Holtzer, H., H. Weintraub, R. Mayne, and B. Mochan. 1972. DNA synthesis, the cell cycle and differentiation. In Current topics in developmental biology (ed. A.A. Moscona and A. Monroyl, Academic Press, New York.

Housman, D., R. Gusella, R. Geller, R. Leveson, and S. Weil. 1978. Differentiation of murine erythroleukemia cells: The central role of the committment event. In Differentiation of normal and neoplastic hematopoietic cells. (ed. B. Clarkson, P.A. Marks, and J.E. Till), Cold Spring Harbor Conf. Cell Prolif. 5: 193-207.

Jansson, M., H. Beug, C. Gray, T. Graf, and B. Vennström. 1987. Defective $v$-erbB genes can be complemented by $v$-erb $A$ in erythroblast and fibroblast transformation. Oncogene. 1: $167-174$. 
Kahn, P., B. Adkins, H. Beug, and T. Graf. 1984. src- and fpscontaining avian sarcoma viruses transform chicken erythroid cells. Proc. Natl. Acad. Sci. 81: 7122-7126.

Kowenz, E., A. Leutz, G. Doederlein, T. Graf, and H. Beug. 1987. ts-oncogene transformed erythroblasts, a novel test system to purify and characterize avian erythroid growth factors. In Modern trends in human leukemia VII (ed. R. Neth, R. Gallo, M. Greaves, and K. Janka) Springer Verlag, Heidelberg (in press).

Lehrach, H., D. Diamon, J.M. Wozney, and H. Boedtcker. 1977. RNA molecular weight determinations by gel electrophoresis under denaturing conditions, a critical reexamination. Biochemistry 16: 4743-4751.

Leutz, A., H. Beug, C. Walter, and T. Graf. 1987. Hematopoietic growth factor glycosylation: Multiple forms of chicken myelomonocytic growth factor. J. Biol. Chem. (in press).

Maniatis, T., E.F. Fritsch, and J. Sambrook. 1982. Molecular cloning: A laboratory manual. Cold Spring Harbor Laboratory, Cold Spring Harbor, New York.

Marks, P. and R. Rifkind. 1978. Erythroleukemic differentiation. Annu. Rev. Biochem. 47: 419-448.

Palmieri, S., H. Beug, and T. Graf. 1982. Isolation and characterization of four new temperature-sensitive mutants of avian erythroblastosis virus (AEV). Virology 123: 296-311.

Radke, K., H. Beug, S. Kornfeld, and T. Graf. 1982. Transformation of both erythroid and myeloid cells by E26, an avian leukemia virus that contains the myb gene. Cell 31: 643653.

Rigby, P.W.J., M. Dieckman, C. Rhodes, and P. Berg. 1977. Labeling deoxyribonucleic acid to high specific activity in vitro by nick translation with DNA polymerase I. I. Mol. Biol. 113: 237-251.

Royer-Pokora, B., H. Beug, M. Claviez, H.J. Winkhardt, R.R. Friis, and T. Graf. 1978. Transformation parameters in chicken fibroblasts transformed by AEV and MC29 avian leukemia viruses. Cell 13: 751-760.

Sap, I., A. Munoz, K. Damm, Y. Goldberg, J. Ghysdael, A. Leutz, H. Beug, and B. Vennström. 1986. The c-erbA protein is a high affinity receptor for thyroid hormone. Nature 324: 635-640.

Schmidt, J.A., J. Marshall, M.J. Hayman, and H. Beug. 1986a. Synthesis and expression of cell surface glycoproteins during chick erythroid differentiation. Differentiation 31: 166173.

Schmidt, J.A., J. Marshall, M.J. Hayman, G. Döderlein, and H. Beug. 1986b. Monoclonal antibodies to novel erythroid differentiation antigens reveal specific effects of oncogenes on the leukemic cell phenotype. Leukemia Res. 10: 257-272.

Schmidt, J.A., J. Marshall, M.J. Hayman, P. Ponka, and H. Beug. 1986c. Control of erythroid differentiation: Possible role of the transferrin cycle. Cell 46: 41-51.

Scotting, P., B. Vennström, M. Jansson, T. Graf, H. Beug, and M.J. Hayman. 1987. Common site of mutation in the erbB gene of avian erythroblastosis virus mutants that are temperature-sensitive for transformation. Oncogene Res. 1: $265-278$.

Staufenbiel, M. and E. Lazarides. 1986. Assembly of protein 4.1 during chicken erythroid differentiation. I. Cell Biol. 102: $1157-1163$.

Van Zant, G. and E. Goldwasser. 1984. Erythropoietin and its target cells. Growth and maturation factors (ed. G. Guroff), J. Wiley and Sons, New York, vol. 2, pp. 186-197.

Woods, C.M., B. Boyer, P.K. Vogt, and E. Lazarides. 1986. Control of erythroid differentiation: Asynchronous expression of the anion transporter and the peripheral components of the membrane skeleton in AEV and S13-transformed cells. $/$. Cell Biol. 103: 1789-1798.

Yamamoto, M., N.S. Yew, M. Federspiel, J.B. Dodgson, N. Hayachi, and J.D. Engel. 1985. Isolation of recombinant cDNAs encoding chicken erythroid $\delta$-aminolevulinate synthase. Proc. Natl. Acad. Sci. 82: 3702-3706.

Yew, N.S., H.R. Choi, J.L. Gallardo, and J.D. Engel. 1987. Expression of cytoskeletal protein 4.1 during avian erythroid cellular maturation. Proc. Natl. Acad. Sci. 84: 1035-1039.

Yoshihara, C.M., J.D. Lee, and J.B. Dodgson. 1987. The chicken carbonic anhydrase-II gene: Evidence for a result shift in intron position. Nucleic Acids Res. 15: 753-770. 


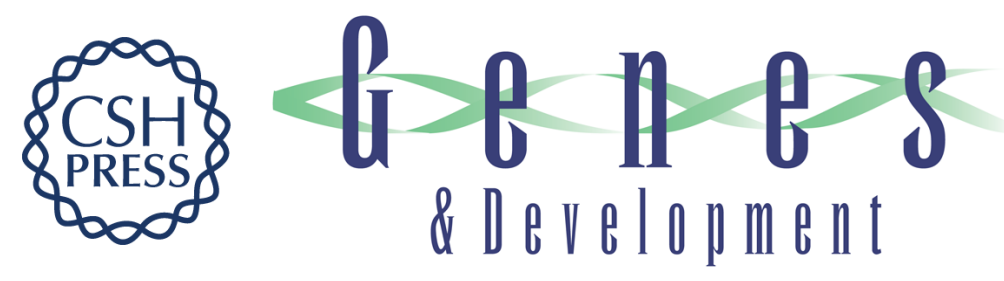

\section{Temperature-sensitive v-sea transformed erythroblasts: a model system to study gene expression during erythroid differentiation.}

J Knight, M Zenke, C Disela, et al.

Genes Dev. 1988, 2:

Access the most recent version at doi:10.1101/gad.2.2.247

References This article cites 46 articles, 10 of which can be accessed free at: http://genesdev.cshlp.org/content/2/2/247.full.html\#ref-list-1

License

Email Alerting

Receive free email alerts when new articles cite this article - sign up in the box at the top Service right corner of the article or click here.

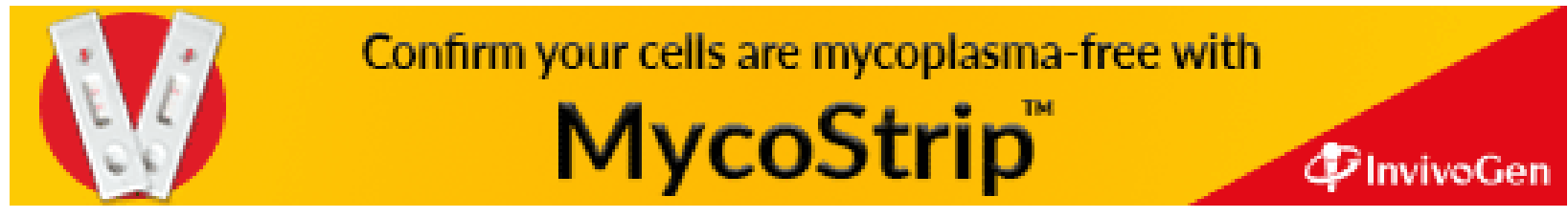

